\title{
A EXPORTAÇÃO DE GADO VIVO NO BRASIL E A REGRA CONSTITUCIONAL DA VEDAÇÃO DA CRUELDADE
}

Recebido: 27.10.2019

\author{
Daniel Braga Lourenço \\ Doutor em Direito pela UNESA/RJ. Professor \\ Permanente do Programa de Pós-Graduação em \\ Direito da UniFG/BA. Professor Adjunto de \\ Biomedicina e Direito Ambiental da UFRJ. \\ E-MAIL: daniel@lourenco.adv.br \\ LATTES: http://lattes.cnpq.br/5869787995233483 \\ ORCID: http://orcid.org/0000-0003-0807-439X
}

\author{
Aprovado: 22.03.2020
}

\author{
Rafael Van Erven Ludolf \\ Mestre pela Universidade Federal Fluminense. \\ Advogado. \\ E-MAIL: rafaelvanerven@gmail.com \\ LATTES: http:/ / lattes.cnpq.br/7463992524509265 \\ ORCID: http://orcid.org/0000-0003-0714-5432
}

\begin{abstract}
RESUMO: A prática de exportação de gado vivo tem sido foco de críticas há décadas no exterior e recentemente no Brasil, girando o debate em torno do bem-estar animal e da violação do direito dos animais. Existe expectativa de crescimento recorde do setor no Brasil para o ano de 2019 devido a abertura de novos mercados. No entanto, tal setor encontrará desafios para assegurar o bem-estar animal, responder às críticas das organizações de defesa animal e das proposições legislativas que visam proibi-la. Nesse contexto, a presente pesquisa tem por objetivo principal avaliar se o transporte de gado vivo viola a regra da vedação da crueldade contra os animais, insculpida na parte final do inciso VII do $\$ 1^{\circ}$ do art. 225 da Constituição Federal. Foi realizada a revisão da literatura nas bases scopus e web of science, buscando mapear as principais discussões sobre a exportação de gado vivo no Brasil e no exterior. Num segundo momento, aplicou-se questionário estruturado a especialistas em Direito Animal, com 8 (oito) afirmações respondidas pela escala likert de 5 (cinco) pontos. Identificou-se que esta prática viola a regra constitucional da vedação da crueldade contra os animais, por ser intrinsicamente cruel, uma vez que a nova ciência do Direito Animal considera que o animal não-humano, senciente, interessa como indivíduo, dotado de valor próprio e, a partir disso, como sujeito do direito fundamental à existência digna, a salvo de práticas cruéis, devendo tal prática ser proibida por lei.
\end{abstract}

PALAVRAS-CHAVE: Exportação de animais vivos. Direito Animal. Bem-Estar Animal. Crueldade.

\begin{abstract}
The practice of exporting live cattle has been the focus of criticism for decades, abroad and recently in Brazil. There are serious alleged problems relative to this practice, including the many violations of animal welfare and of animal rights. Record growth is expected for this sector in Brazil for 2019 due to the opening of new markets. However, the live export industry will face growing challenges in ensuring animal welfare, responding to criticism from animal welfare organizations and facing legislative proposals aimed at banning it. In this context, this research aims to evaluate whether the transport of live cattle violates the rule of prohibiting cruelty to animals, inscribed in the final part of item VII of $\$ 1$ of article 225 of the Federal Constitution of Brazil. A literature review was performed in the scopus and web of science databases, seeking to map the main discussions on live cattle exports in Brazil and abroad. Secondly, a structured questionnaire was applied to specialists in Animal Law, with 8 (eight) statements answered by the 5 (five) points likert scale. It has been found that this practice violates the constitutional rule of prohibiting cruelty to animals, as it is intrinsically
\end{abstract}

53 | Revista Brasileira de Direito Animal, e -issn: 2317-4552, Salvador, volume 15, n. 03, p.53 - 73, Set - Dez 2020 
cruel, since animal law considers that the non-human sentient animal have individual interests and inherent value and thereafter is a right holder of the fundamental right to a dignified existence, save from cruel practice. The live export industry should be banned.

KEYWORDS: Exports of live animals. Animal law. Animal welfare. Cruelty.

SUMÁRIO: 1 Introdução 2 Revisão da Literatura 2.1 A exportação de animais vivos na Austrália 2.2 A exportação de gado vivo no Brasil 3 Questionário estruturado 3.1 Análise e discussão 3.1.1 Afirmativa 1 3.1.2 Afirmativa 2 3.1.3 Afirmativa 3 3.1.4 Afirmativa 4 3.1.5 Afirmativa 5 3.1.6 Afirmativa 6 3.1.7 Afirmativa 7 3.1.8 Afirmativa 84 Conclusão 5 Referências

\section{Introdução}

Segundo a ABREAV, a exportação de animais vivos cresceu $80 \%$ e chegou a 750 mil cabeças em 2018, atingindo volume recorde e com expectativa de embarcar 1 milhão de animais em 2019. Em nota conjunta em janeiro de 2019, os Ministérios de Relações Exteriores e Agricultura do Brasil noticiaram que a Malásia abriu seu mercado para exportações brasileiras de bovinos vivos para abate, país que tem mais de 30 milhões de habitantes e importa cerca de $80 \%$ da carne bovina que consome. Já em maio do mesmo ano, a ministra da Agricultura Tereza Cristina anunciou que visitou quatro populosos países da Ásia: Japão, China, Vietnã e Indonésia com o objetivo central de ampliar as exportações brasileiras. O Brasil é o quarto maior exportador de bovinos vivos do mundo, junto com Austrália, México e União Europeia. Possui protocolos sanitários firmados com mais de 15 países e compromissos comerciais vigentes com pelo menos 4 países: Egito, Turquia, Jordânia e Líbano.

Todavia, no início de 2018 deflagrou-se no Brasil um embate jurídico, social e legislativo envolvendo o navio panamenho MV NADA que, atracado no porto de Santos/SP com 25.193 mil bovinos com destino à Turquia, foi proibido de seguir viagem por decisão judicial, que impediu também a exportação de animais vivos em todo o território nacional. Tal decisão foi suspensa posteriormente pelo Tribunal Regional Federal da Terceira Região - TRF-3, sob o argumento de lesão à ordem administrativa, à saúde e economia públicas, liberando a embarcação de seguir viagem.

Este fato foi motivo de atenção da mídia, pecuaristas, juristas e organizações de defesa animal, resultando em manifestações públicas e proposições legislativas visando a sua proibição, fatos que merecem ser analisados para se investigar se esta prática viola a regra constitucional da vedação de crueldade contra os animais, regra pela qual a nova ciência jurídica do Direito Animal postula como marco inicial para sua autonomia científica, e que segue em franco desenvolvimento constitucional, legal, jurisprudencial e doutrinário no Brasil.

O Tribunal Regional Federal da 3a Região julgou o pedido de proibição, concluindo com 10 (dez) votos favoráveis e 7 (sete) contrários à manutenção da prática. Em resumo, dos 10 (dez) desembargadores que votaram a favor da manutenção da prática o argumento predominante foi de ordem econômica, os outros 7 (sete) contrários afirmaram a irrelevância econômica da prática para o PIB brasileiro bem como destacaram o caráter inerentemente cruel da prática em relação aos animais e ao meio ambiente.

Conflitante e apertada as opiniões sobre esta atividade, pois, de um lado, se pleiteia a proibição desta prática sob o argumento de ser inerentemente cruel aos animais, agressivo ao meio ambiente e financeiramente irrelevante. De outro, defende-se a manutenção deste comércio em razão do relevante percentual financeiro das exportações brasileiras e que se tem investido em tecnologia para cumprir as normas de bem-estar animal. 
Trata-se de duas lógicas absolutamente diversas: uma que entende que os animais têm valor instrumental, alinhados a uma cultura antropocêntrica e especista que visa o benefício exclusivamente humano, e outra para a qual o animal não-humano, senciente, detém valor intrínseco, e que deve ser protegido de tal prática por ser ela inerentemente cruel.

Nesse imbróglio, surge a nova ciência do Direito Animal, que se encontra em vias de se consolidar nas dimensões constitucional, legal, jurisprudencial e doutrinário no Brasil, estabelecendo, como marco inicial para sua autonomia científica a regra da proibição da crueldade contra os animais, insculpida no inciso VII do $\$ 1$ o do art. 225 da Constituição Federal.

Para esse novo campo do Direito, o animal não-humano interessa como indivíduo, dotado de dignidade própria e, a partir disso, como sujeito do direito fundamental à existência digna, colocado, portanto, a salvo de práticas cruéis. Se fundamenta em fontes normativas federais gerais, como o Decreto n. 24.645/34 (que muitos sustentam ainda estar em vigor em decorrência do fato de o Decreto n. 11/91 não poder tê-lo revogado em razão de ser um Decreto meramente executivo e o Decreto n. 24.645/34, dotado, materialmente, de força legal, em virtude de edição em época de regime de exceção) e o art. 32 da Lei n. 9.605/98 (tipo penal de maus-tratos a animais), bem como de outros diplomas estaduais e municipais, além de emblemáticos julgamentos, como da ADI n. 4983/CE (caso da análise da constitucionalidade da prática da vaquejada) no Supremo Tribunal Federal - STF), dentre outros.

Nesse contexto, portanto, diante das críticas sobre o desrespeito ao bem-estar animal e da expectativa de crescimento recorde do mercado e da atividade de exportação de animais vivos, decerto que existirão contínuos desafios para responder às críticas das organizações de defesa animal e às proposições legislativas que visam limitar ou proibir tal atividade, como também para garantir a conformidade à regra constitucional de proibição de crueldade contra os animais, matéria que concerne a nova ciência do Direito Animal.

Oportuno frisar que tal discussão fez surgir ao menos quatro proposições legislativas, visando proibir esta prática. Como exemplo podemos citar o PL n. 9.464/2018 na Câmara dos Deputados (arquivado), o PL n. 31/2018 no Estado de São Paulo (em tramitação), a Lei Complementar n. 996/2018 do Município de Santos/SP, declarada inconstitucional pelo STF, e o projeto de lei do Senado Federal n. 357/2018 (em tramitação).

Isto posto, este trabalho formula sua questão de pesquisa, que é saber se a atividade de exportação de animais vivos viola a regra de proibição de crueldade contra os animais insculpida na parte final do inciso VII do $\$ 10$ do art. 225 da Constituição Federal, à luz dos parâmetros que regulam a ciência do bem-estar animal e dos princípios que regem o Direito Animal.

\section{Revisão Da Literatura}

Realizou-se revisão da literatura nos meses de janeiro e fevereiro de 2019, nas bases de dados Scopus (Elsevier) e Web of Science (Thomson Reuters Scientific), por meio do portal de periódicos CAPES, com o objetivo de localizar quais as principais críticas sobre o comércio de exportação de animais vivos no Brasil e no exterior. Também foram utilizados Dissertações de mestrado e Teses de doutorado escritos na língua portuguesa e inglesa, além de conteúdo de livros adquiridos e disponíveis em biblioteca.

Encontrou-se nas referidas bases um total de 552 trabalhos, estabelecendo-se como limite o ano de 2012. Em seguida, filtrou-se somente para artigo e revisão, resultando em 233. Desses, foram identificados somente 10 trabalhos alinhados diretamente ao objetivo da pesquisa, pois os demais apesar de abordarem a exportação de animais vivos focavam em outros ângulos e não no sofrimento dos animais submetidos a esta prática. 
Excepcionalmente, utilizou-se um trabalho de 2008, que apesar de além do limite estabelecido, foi o único trabalho crítico à exportação brasileira, relacionado diretamente aos objetivos desta pesquisa, justificando-se, portanto, a sua inclusão.

\subsection{A exportação de animais vivos na Austrália}

Quase a totalidade dos trabalhos encontrados nas bases Scopus e Web of Science sobre a exportação de animais vivos são da Austrália, país que se encontra entre os líderes e pioneiros no comércio de exportação de animais vivos. A vasta produção acadêmica em várias áreas do conhecimento sobre esta prática se mostrou avançada em relação aos países concorrentes, sobretudo o Brasil, que apenas recentemente começou a discutir este comércio, constatável pela escassez de trabalhados acadêmicos sobre este setor nas citadas bases.

Desse modo, justifica-se discorrer sobre os desafios enfrentados por este comércio na Austrália e seus desdobramentos, buscando extrair daí experiências que ajudem a pensar o comércio de exportação de gado vivo realizado pelo Brasil.

Segundo Sinclair et al. (2018), o comércio de exportação de animais vivos na Austrália tem sido foco de severas críticas, repúdio público e revisões sistemáticas do governo desde 1985, girando o debate em torno do desrespeito ao bem-estar animal. Até mesmo repetidas suspensões das atividades vem ocorrendo, em razão de acidentes no transporte marítimo, surto de doenças e publicação na mídia de vídeos e imagens que denunciaram crueldades aos animais.

Diversos trabalhos demonstraram variadas evidências contundentes de maus-tratos aos animais exportados por via marítima na Austrália, violando os indicadores de bem-estar animal internacionalmente conhecidos como "as cinco liberdades" (liberdade da dor e da sede; liberdade de desconforto; liberdade de dor, ferimentos ou sofrimento; liberdade para expressar comportamento normais típicos da espécie; e liberdade de medo e angústia), sendo possível identificar os dez fatores de mortalidade que mais vezes apareceram nos trabalhos consultados. Para facilitar a visualização, elaborou-se a Figura 1, abaixo:

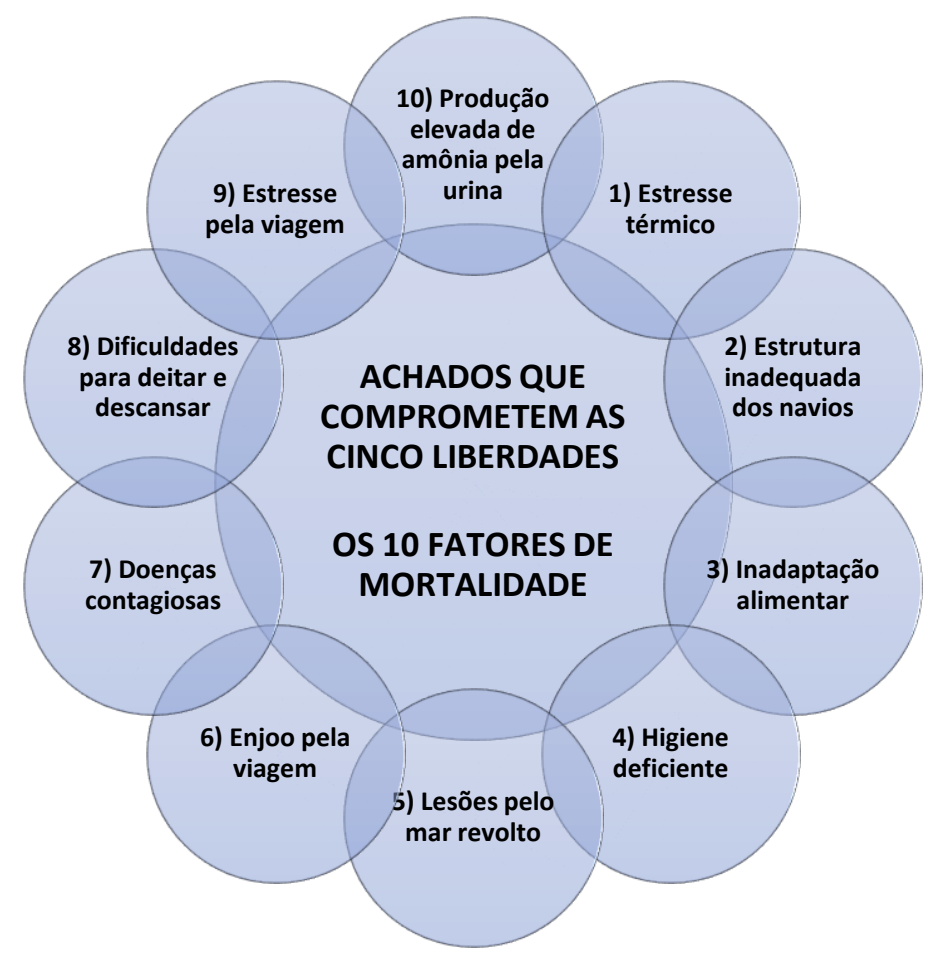

Figura 1 - Achados que comprometem as cinco liberdades.

Fonte: Elaborado pelos autores, 2019 
Sinclair et al. (2018) narram que os resultados de suas pesquisas mostram objetivamente que longas viagens de navio são estressantes para bovinos e ovinos, já que estes animais estão acostumados a uma existência na terra (restrição da liberdade ambiental e de expressão de comportamentos naturais), podendo experimentar sofrimento agudo durante toda a viagem, que pode ter duração até três semanas.

Simpson (2018), médica veterinária, que trabalhou no comércio de exportação de gado em pé desde 1999, navegando por mais de uma década transportando gado da Austrália até muitos portos do hemisfério norte, emitiu relatório afirmando que este comércio não cumpre o Código Sanitário para Animais Terrestres - OIE. Seu relatório aborda os riscos e impactos potenciais para o bem-estar dos animais ao longo de todas as rotas internacionais. A evidência visual de seu relatório mostra que as atuais consequências para a saúde e bem-estar animal e segurança alimentar nas embarcações utilizadas para transporte de animais são inaceitáveis pelos padrões da OIE, de médicos veterinários e da saúde pública.

Afirma que o gado transportado por mar tem seu bem-estar comprometido. Muitos animais sofrem de problemas de saúde, incluindo e não limitado a disseminação de doenças, lesões e dor desnecessárias causadas pela infraestrutura, estresse e sofrimento por serem transportados por longos períodos. Doenças contagiosas comumente encontradas são pneumonia ("febre de embarque"), Salmonelose e Moraxella bovis ("olhos vermelhos"). Essas doenças se disseminam devido à natureza artificial do ambiente das embarcações, alta densidade, higiene deficiente e ventilação forçada, geralmente resultando em óbitos.

Enfatiza que as "cinco liberdades" são muitas vezes comprometidas devido ao manejo, à infraestrutura e aos riscos inerentes a esse tipo de transporte, que inclui avarias mecânicas tais como danos na ventilação, falhas na distribuição de forragem ou de água, e lesões nos animais causadas por mar revolto pois são jogados de um lado para o outro contra paredes sólidas e grades dentro de seus reduzidos recintos.

Discorre ainda em seu relato que anualmente morrem muitos animais devido à sua má adaptação às rações dadas a bordo, ao estresse térmico causado pela deficiente aclimatação durante o trânsito por grande distância e mudanças climáticas sazonais. As doenças propagadas devido a higiene deficiente e alta densidade de animais exacerbam esses desafios assim como a capacidade do sistema de imunidade do animal para fazer face a seus efeitos.

Por fim, afirma a veterinária que lesões são comuns, como membros quebrados e septicemia devido a abrasões prolongadas nas patas, causadas pelo piso duro e leitos insuficientes. Essas lesões exigem geralmente que animais sejam eutanasiados devido à duração e gravidade delas nesse ambiente artificial. Seus corpos são então jogados ao mar.

Phillips e Santurtun (2013) demonstraram que o estresse por calor tem sido identificado como um fator significativo que contribui para a alta mortalidade em viagens de exportação de animal vivo na Austrália. Já Collins, Hampton e Barnes (2018) realizaram uma revisão sistemática da carga térmica no transporte de animais vivos por via marítima na Austrália, e constaram que a mortalidade do gado devido a carga excessiva de calor pode ocorrer em várias condições, incluindo no confinamento e durante o transporte. Afirmam ainda que a preocupação pública para o bem-estar dos animais transportados é bastante elevada e a mídia vem expondo esta prática sobre os efeitos negativos da carga de calor, sobretudo nos transportados de animais vivos da Austrália para o Oriente Médio, especialmente durante o verão no hemisfério norte.

Caulfield et al. (2014) narram que o estresse por calor é um dos principais contribuintes para a violação do bem-estar animal na exportação marítima por longa distância, e que o estresse térmico é uma das principais causas de mortalidade em ovinos e bovinos.

Agravante para a temperatura e o estresse térmico é a produção de amoníaco, em particular por degradação de urina, que pode reduzir ainda mais a capacidade dos animais para

57 | Revista Brasileira de Direito Animal, e -issn: 2317-4552, Salvador, volume 15, n. 03, p.53 - 73, Set - Dez 2020 
dissipar o calor por meio de aumento da frequência respiratória. Isto porque as concentrações elevadas de amoníaco prejudicam a função respiratória normal, segundo Phillips e Pine (2013).

Moore et al. (2014) pesquisaram a mortalidade do gado vivo na exportação em viagens de longa distância da Austrália e suas alterações patológicas e patógenos, com base em relatórios de necropsia e amostras coletadas em viagens, verificando que as taxas de mortalidade e bem-estar animal estão intimamente ligados e que o aumento da mortalidade é um indicador de comprometimento do bem-estar.

Afirmam ainda que o estresse por calor é um problema típico dos navios de exportação, incluindo o encabeçamento a bordo do navio, a temperatura ambiente elevada e a umidade, particularmente na região equatorial e nas águas em volta da Península Arábica. Como diagnóstico final, agruparam as causas de morte em nove categorias e destacaram a doença respiratória como a causa mais comum de morte, representando cerca de $50 \%$ de mortes global.

Sinclair et al. (2018) aplicaram questionários antes e depois de uma exposição de crueldade aos carneiros a bordo de navios destinados para o Oriente Médio em 2017. O mais recente, respondido por 522 pessoas, indicaram que a maior parte do público australiano tem opiniões negativas sobre o comércio de exportação de animais vivos. Além disso, o estudo indicou que a maioria dos entrevistados desejam o fim deste comércio.

Buddle, Bray e Ankeny (2018) discorrem que a preocupação com o bem-estar do gado tem aumentado significativamente em muitas partes do mundo, sobretudo no transporte de gado vivo. Utilizando métodos de pesquisa qualitativa, realizaram uma pesquisa que explorou as preocupações dos consumidores de carne australianas relacionados às práticas de transporte de gado vivo e afirmaram que a maioria do público australiano não suporta este comércio.

\subsection{A exportação de gado vivo no Brasil}

Apenas um trabalho crítico sobre a exportação de gado vivo no Brasil foi encontrado nas bases pesquisadas. Se trata do trabalho de Gonçalves (2008), que aponta que o transporte por longas distâncias de bovinos vivos no Brasil para abate no exterior implica inúmeros problemas e riscos, e que além de desnecessária e cruel, é injustificável economicamente. Enumera problemas como doenças infecciosas, dano à carcaça, diminuição da qualidade da carne e mortalidade, fatores que reduzem o valor da carne exportada.

Alega ainda problemas estruturais próprios de produtos primários com baixo valor agregado como, por exemplo, menor dinamismo do mercado internacional, baixa elasticidaderenda da demanda e elasticidade-preço desfavorável. Ademais, afirma que este tipo de produto primário não tem efeitos de transbordamento (spillovers) positivos sobre a economia doméstica. Ou seja, a exportação de bovinos vivos gera padrão de comércio exterior retrógrado que impede a modernização do aparelho produtivo nacional e, portanto, reduz o potencial de desenvolvimento econômico e social do país.

Aduz, portanto, que o gado bovino deve ser abatido o mais próximo possível das fazendas de origem e a exportação de bovino vivo deve ser substituída pela exportação de carne refrigerada e congelada. Para tanto, sugere as seguintes diretrizes estratégicas: legislação que limite a distância e o tempo de transporte; proibição do transporte por longas distâncias; limites para o tempo de duração do transporte; abate de animais o mais próximo possível da fazenda de origem; substituição da exportação de animais pela exportação de carne.

Narra que a proibição poderia ocorrer de imediato ou, então, a partir de um cronograma de restrições quantitativas, por exemplo, por um período de dois anos. Apresenta um cronograma para redução de $25 \%$ da quantidade exportada no primeiro ano e $60 \%$ no segundo. Desta forma, as exportações são zeradas no terceiro ano após a decisão. Encerra 
sugerindo que este cronograma permitiria a reestruturação produtiva no sentido de substituir a exportação de bovino vivo pela exportação de carne refrigerada e congelada.

Vale ressaltar a crescente crítica da sociedade brasileira e estrangeira ao setor de exportação de gado vivo. Por exemplo, pelo terceiro ano consecutivo, um movimento internacional, liderado pela organização não governamental Compassion in World Farming, mobiliza a população mundial em torno do "Dia Internacional contra a Exportação de Gado Vivo", celebrado anualmente no dia 14 de junho, com o objetivo de conscientizar as pessoas sobre o sofrimento dos animais que são exportados vivos.

O movimento foi iniciado em 2017 e contou com 30 países participantes. O Brasil aderiu em 2018. Este ano, 41 países fizeram manifestações. No Brasil elas foram coordenadas pelo Fórum Nacional de Proteção e Defesa Animal (FNPDA), em conjunto com organizações de diversas cidades. Ao todo, 12 cidades brasileiras participam do movimento global.

O Fórum Animal e a Animals International atuam contra a exportação de gado vivo desde 2016 no Brasil, quando o comércio ainda era quase desconhecido pela sociedade brasileira. É também de autoria do Fórum Animal a ação civil pública citada neste trabalho.

Outra crítica relevante, é do Grupo de Estudos e Pesquisas em Etologia e Ecologia Animal - ETCO da Faculdade de Ciências Agrárias e Veterinárias - UNESP, campus de Jaboticabal, que publicou o "MANIFESTO SOBRE AS CONDIÇÕES DE BEM-ESTAR DOS BOVINOS EMBARCADOS NO "NADA": UMA REFLEXÃO SOBRE OS ÚLTIMOS ACONTECIMENTOS DURANTE A EXPORTAÇÃO DE BOVINOS NO PORTO DE SANTOS" em 16 de fevereiro de 2018.

Se trata de um manifesto subscrito por 14 renomados pesquisadores da ciência do bem-estar animal de importantes universidades brasileiras, que, no mesmo passo do relatório da veterinária Dr.a Lynn Simpson, ressalta o descumprimento do Código Sanitário - OIE, do qual o Brasil é signatário e, portanto, assume compromissos em respeitá-lo.

O manifesto ressalta que não há como negar a existência de problemas de bem-estar dos bovinos que participaram desta operação, ante as evidências, e que o MAPA está devendo regulamentações com bases científicas sobre a cadeia de transporte de gado vivo.

\section{Questionário Estruturado}

A opção de uso do questionário estruturado se justifica pela necessidade de captação de dados a respeito do entendimento do Direito Animal sobre a submissão dos animais à prática de exportação de gado vivo. O questionário foi enviado exclusivamente a especialistas em Direito Animal. As questões foram elaboradas no formato de afirmações, de modo a investigar a questão de pesquisa e os dados foram coletados por meio de questionário survey.

O questionário foi enviado a 34 especialistas, pelo critério de acessibilidade, a partir do dia 19/06/2019 e o processo de coleta desses dados terminou em 19/07/2019. Ao final deste período constatou-se 30 respostas.

As 8 afirmações, sustentadas pelo referencial teórico com adaptações à realidade do setor de exportação de animais vivos do Brasil, foram respondidas pela escala likert de 5 pontos.

Escolheu-se o seguinte critério para a escolha dos membros da amostra: indivíduos notoriamente conhecidos pela sua atuação no campo do Direito Animal, tendo como base publicações científicas, livros ou formação na área do Direito Animal.

Buscou-se captar os sentimentos e opiniões dos especialistas, no caso, se a prática em estudo viola ou não a regra de proibição constitucional de crueldade contra os animais segundo a nova ciência jurídica do Direito Animal e, portanto, se deve ou não ser proibida.

O questionário não se preocupou em identificar os dados dos respondentes, como sexo ou região. Suas identidades foram preservadas. 
Os questionários foram enviados via e-mail e whatsapp. Dos 20 questionários enviados via e-mail 14 foram respondidos, 3 retornaram com endereço de e-mail errado e 3 não foram respondidos. Por whatsapp foram enviados 16 questionários, sendo todos respondidos, chegando-se a um total de 30 respostas.

O roteiro do questionário foi elaborado de forma a coletar a visão da nova ciência do Direito Animal para responder à questão de pesquisa, aliado ao referencial teórico levantado.

Dividiu-se o roteiro em quatro blocos principais: (1) mapeamento do entrevistado; (2) percepção do status animal para o Direito Animal; (3) percepção do conceito de crueldade para o Direito Animal; (4) percepção se a prática em estudo viola a regra constitucional de proibição de crueldade contra os animais.

\subsection{Análise E Discussão}

Aqui são apresentados os resultados da pesquisa, utilizando-se tabelas e gráficos que sintetizam os dados quantitativos e qualitativos obtidos através do questionário estruturado. Para tabulação dos dados, foram consideradas as 30 respostas ao questionário. 


\subsubsection{Afirmativa 1}

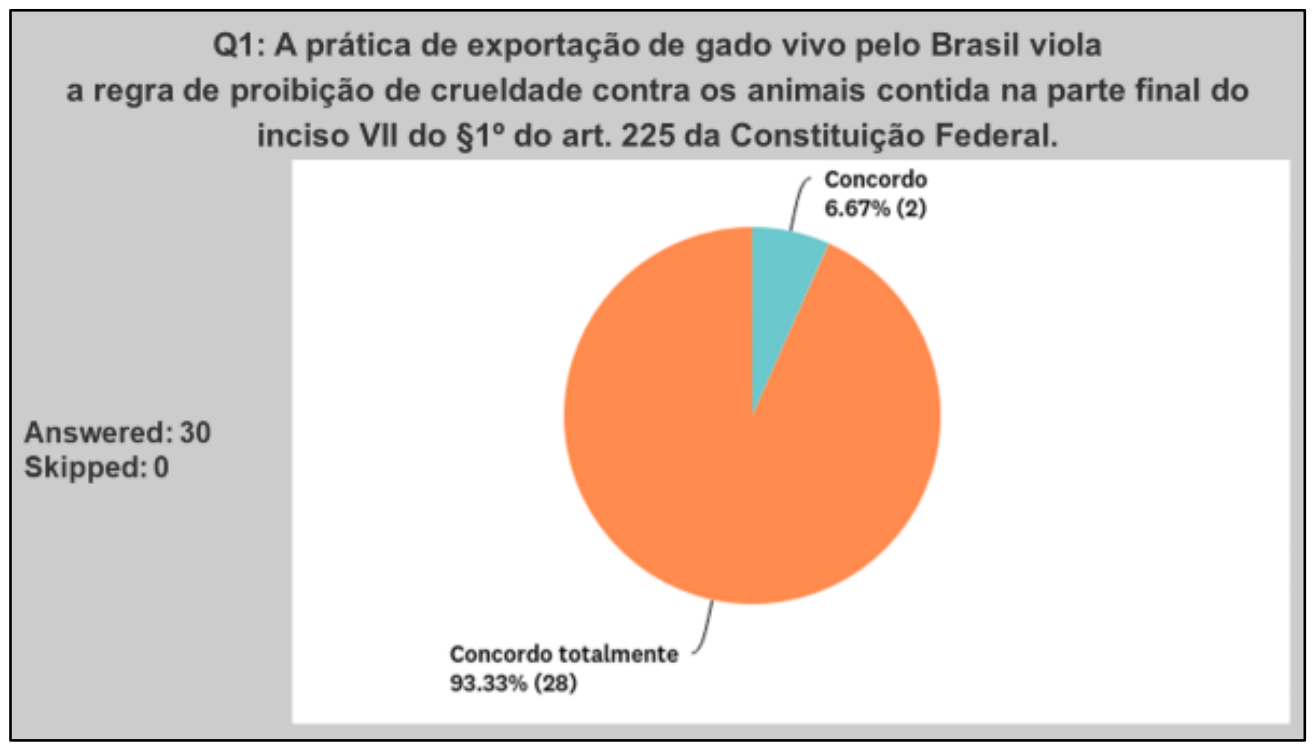

Gráfico 1 - Resultados obtidos na Afirmação 1

Fonte: Dados da pesquisa - ferramenta Survey

A primeira afirmação investigou, de pronto, a questão de pesquisa, ou seja, se a prática de exportação de gado vivo submete os animais à crueldade, violando o art. 225, §1으, VII da Constituição Federal. Conforme o Gráfico 1, 93,33\% dos respondentes concordam totalmente e 6,67\% concordam com a afirmação, não ocorrendo qualquer indiferença ou discordância parcial ou total da afirmação. Este resultado demonstra que o Direito Animal entende que estes animais são submetidos à crueldade na prática de exportação de gado vivo, violando a Constituição Federal e a integridade física e psíquica destes animais sencientes.

Diz Ataíde Junior (2018), que para esse novo campo do Direito, o animal não-humano interessa como indivíduo, dotado de dignidade própria e, a partir disso, como sujeito do direito fundamental à existência digna, posta a salvo de práticas cruéis, tendo como base não só a regra constitucional da proibição da crueldade, também o Decreto 24.645/1934 e o art. 32 da Lei 9.605/1998.

Narra, ainda, que da regra constitucional da proibição da crueldade - e dos princípios que também emanam do mesmo dispositivo constitucional, como o princípio da dignidade animal e o princípio da universalidade - é que exsurge o direito fundamental animal à existência digna. É direito fundamental - e não apenas objeto de compaixão ou de tutela -, porquanto é resultado da personalização e positivação do valor básico inerente à dignidade animal (ATAÍDE JUNIOR, 2018).

Essa resposta, igualmente, corrobora com o referencial teórico, especificamente com os 10 maiores fatores de mortalidade que violam as "cinco liberdades" dos animais, que não ocorrem tão somente no transporte marítimo, mas desde o pré-embarque, ainda no transporte terrestre, podendo se enquadrar na definição de crueldade da resolução 1236/2018 do CFMV (Conselho Federal de Medicina Veterinária) e até mesmo na antropocêntrica interpretação dos tribunais brasileiros quando limitam o vocábulo crueldade ao "sofrimento desnecessário". 


\subsubsection{Afirmativa 2}

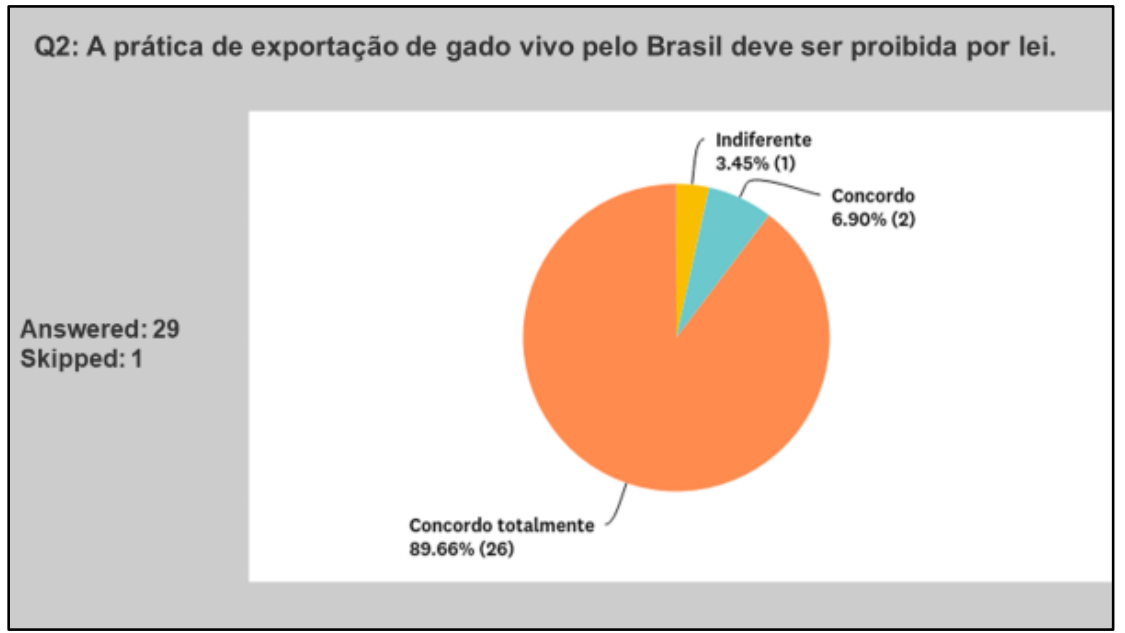

Gráfico 2 - Resultados obtidos na Afirmação 2

Fonte: Dados da pesquisa - ferramenta Survey

A segunda afirmação investigou se a prática deve ser proibida por lei, conforme o Gráfico 2, $89,66 \%$ concordaram totalmente e $6,90 \%$ concordaram, ocorrendo apenas $3,45 \%$ de indiferença, representando apenas 1 respondente, demonstrando que a maioria dos respondentes são favoráveis a proibição através de lei.

Corroborando com esta afirmativa, o trabalho de Gonçalves (2008) classificou o transporte de animais vivos como uma prática além de desnecessária e cruel, injustificável economicamente, pleiteando sua proibição.

Oportuno mencionar também que já existem iniciativas de lei visando proibir esta prática, por exemplo, o PL 9464/2018 na Câmara dos Deputados (arquivado), o PL 31/2018 no Estado de São Paulo (em tramitação), a Lei Complementar no 996/2018 do Município de Santos/SP, declarada inconstitucional pelo STF, e o projeto de lei do Senado Federal no 357/2018 (em tramitação).

Merece destaque o parecer do biólogo Frank Alarcón realizado em 17 de janeiro de 2018 sobre o transporte de animais vivos, que descreveu com riqueza de detalhes o tratamento dispensado aos animais destinados à exportação desde o campo até o embarque no navio, demonstrando que os sofrimentos aos animais se iniciam bem antes, já no transporte rodoviário até a região portuária onde serão embarcados em navios de grande porte. A operação total desde a origem até o seu destino dura em torno de 80 a 100 dias.

Afirmou o biólogo que não somente estão sendo feridos de forma clara as diretrizes oferecidas pela Constituição Brasileira, na forma de seu artigo 225, § 1ㅇ , inciso VII, assim como é também maculada de maneira torpe o disposto na Lei de Crimes Ambientais (Lei 9605/1998), na forma de seu artigo $32, \S 1$ o, os quais em conjunto, qualificam todo o corpo das atividades aqui citadas como evidentes maus tratos cometidos contra vulneráveis, a saber, animais nãohumanos.

Outrossim, sobre a ação civil pública envolvendo o navio MV NADA, vale mencionar que o magistrado atuante no primeiro grau concedeu integralmente a medida liminar, suspendendo a partida da embarcação, somente após a inspeção por médico veterinário. A perícia realizada concluiu que o transporte de animais por longos períodos e distâncias, seja por meio terrestre como por meio marítimo, sujeitamos animais a uma experiência completamente alheia à sua 
natureza originária, comprometendo todas as cinco liberdades preconizadas pelo Conselho Federal de Medicina Veterinária (CFMV) durante todo o processo de transporte.

Afirmou a veterinária que são abundantes os indicativos que comprovam maus-tratos e violação explícita da dignidade animal, violando critérios elementares de bem-estar, arrematando que a prática de transporte marítimo de animais por longas distâncias está intrínseca e inerentemente relacionada à causação de crueldade, sofrimento, dor, indignidade e corrupção do bem-estar animal sob diversas formas. 


\subsubsection{Afirmativa 3}

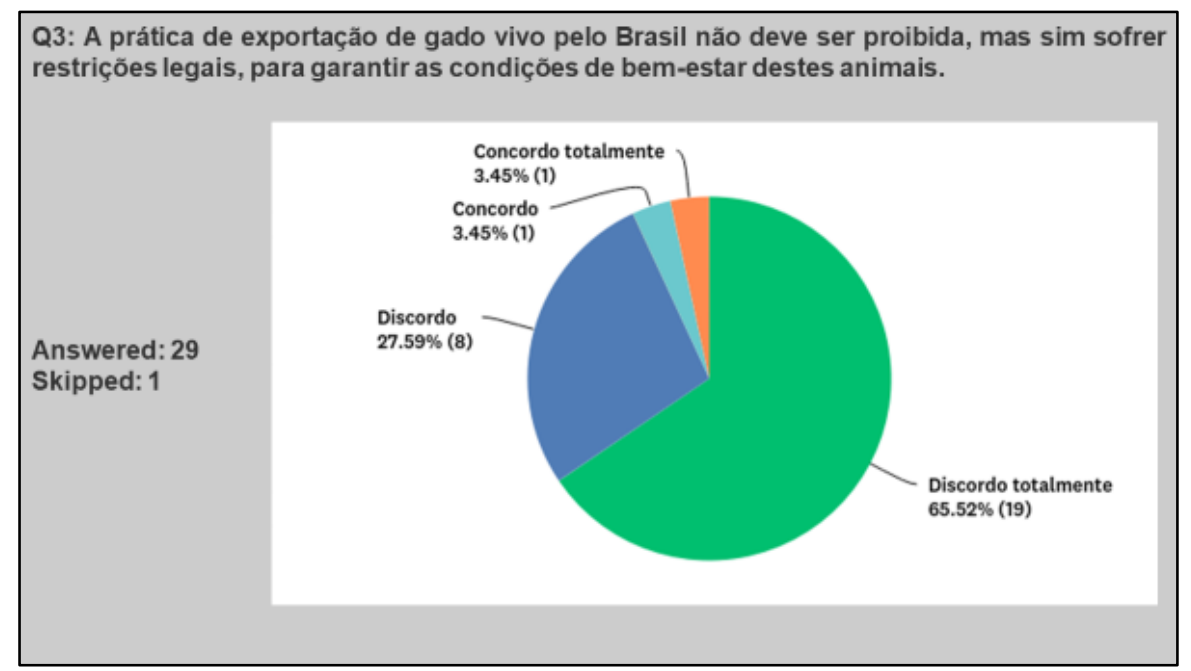

Gráfico 3 - Resultados obtidos na Afirmação 3

Fonte: Dados da pesquisa - ferramenta Survey

A terceira afirmação investigou se bastaria que a prática sofresse restrições legais, ao invés de ser proibida. $65,52 \%$ discordaram totalmente e $27,59 \%$ discordaram da afirmação. Apenas 2 respondentes concordaram total e parcialmente, representando 3,45\% cada um.

Este resultado confirma a afirmativa 2 , já que a maioria absoluta respondeu que a prática deve ser proibida, corroborando com o referencial teórico, as quais evidenciaram que a crueldade contra os animais é inerente à prática de exportação de animais vivos, não bastando que ocorra maior fiscalização ou restrição legal para garantir a cessação do sofrimento físico e psíquico dos animais submetidos a esta prática.

Segundo Gordilho (2008), a partir da Constituição Federal de 1988 pode-se concluir, sob o prisma de uma interpretação vanguardista e sistemática, que os animais podem também ser considerados sujeitos de direito. Para tais intérpretes, os animais possuem pelo menos um direito, em decorrência do texto constitucional: o de não serem submetidos a tratamentos cruéis.

Levai (2001) afirma que no paradigma jurídico tradicional os animais - embora 'seres vivos dotados de sensibilidade e movimento próprio' - não são considerados por sua natureza intrínseca, mas em função de um interesse humano subjacente. O direito positivo brasileiro, inspirado na doutrina romana clássica, trata os animais - em regra - sob a ótica privatista, o que se pode perceber facilmente pelas expressões "coisas", "semoventes", "propriedade", "recursos" ou "bens", terminologia essa que nada mais é do que uma confissão espontânea de nosso egoísmo de espécie. Dessa forma, tal resposta, aponta como que o Direito Animal contribui para superar este paradigma tradicional, reconhecendo o valor intrínseco dos animais não-humanos e fazendo coro ao cumprimento da regra constitucional de vedação da crueldade. 


\subsubsection{Afirmativa 4}

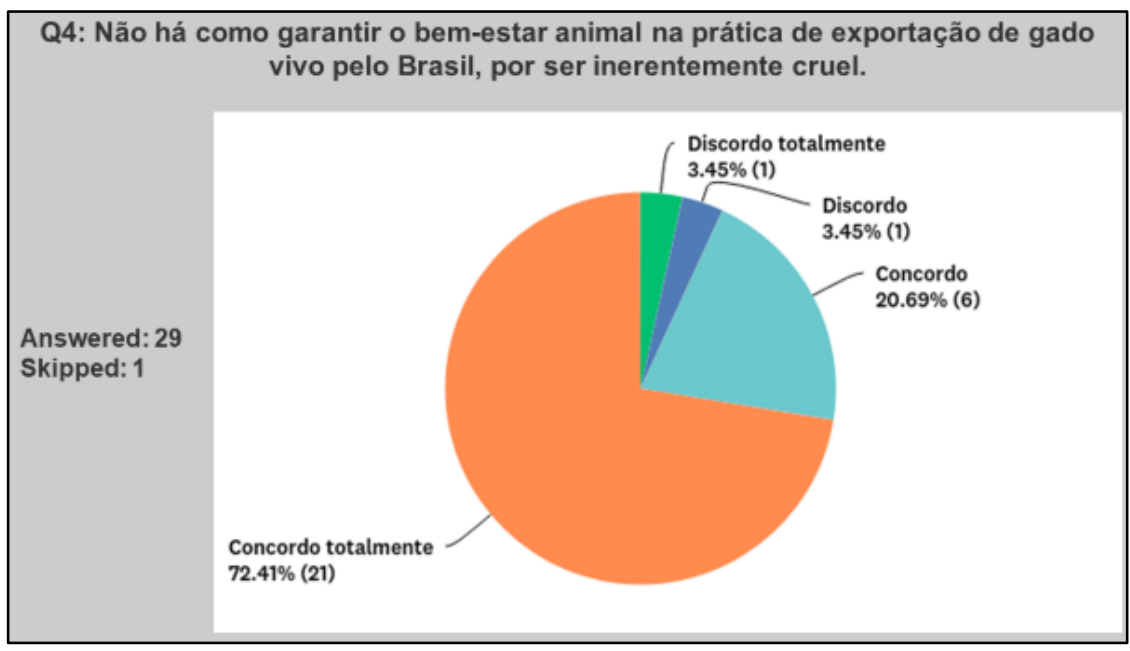

Gráfico 4 - Resultados obtidos na Afirmação 4

Fonte: Dados da pesquisa - ferramenta Survey

Seguindo a análise, a quarta afirmação reforçou o tema da causação de crueldade aos animais, afirmando que a prática é inerentemente cruel. $72,41 \%$ concordaram totalmente com a afirmação e 20,69\% concordaram, conforme apresentado no Gráfico 4. Também aqui, a discordância total ou parcial, foi de apenas 3,45\% para cada opção. A maioria, novamente, afirmou que a prática é cruel.

Mais uma vez, o resultado se alinha aos 10 fatores de mortalidade que mais apareceram no referencial teórico, conforme a Figura 1, os quais demonstram que, como afirmou Simpson (2018), que não há como garantir as cinco liberdades na exportação de animais vivos, que sequer respeita o Código Sanitário Para Animais Terrestres - OIE.

Vale frisar que nos autos da ação CIVIL PÚBLICA envolvendo o navio MV NADA, quatro qualificadas médicas veterinárias emitiram parecer sobre o transporte marítimo de gado vivo, com fundamento na literatura científico-acadêmica, relatos de médicos veterinários com experiência na área de transporte de animais vivos, na ciência do bem-estar animal e nos preceitos éticos que devem nortear qualquer atividade que envolva o uso de animais, qualificando o transporte como prática hedionda e inconcebível, pleiteando, por conseguinte, sua proibição em nível federal.

As 4 médicas veterinárias descrevem as condições a que os animais são submetidos no transporte marítimo para exportação, tendo como base o conceito das cinco liberdades, e concluíram, mediante 22 constatações, que a prática de exportação de animais vivos é inerentemente cruel, pleiteando, por conseguinte, sua proibição em nível federal. 


\subsubsection{Afirmativa 5}

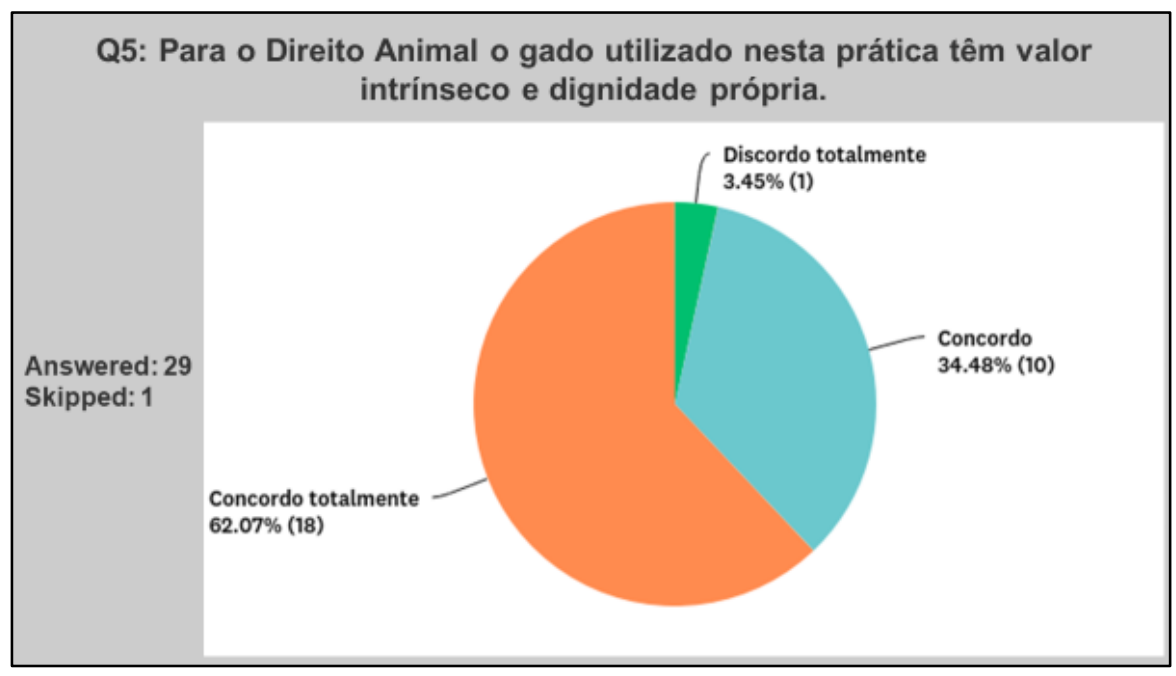

Gráfico 5 - Resultados obtidos na Afirmação 5

Fonte: Dados da pesquisa - ferramenta Survey

Sobre a dignidade dos animais submetidos à prática em estudo, tema muito caro ao Direito Animal, a afirmativa 5 investiga se eles têm valor intrínseco, conforme o Gráfico 5 . Novamente, a maioria, $62,07 \%$ dos respondentes, concordaram totalmente e $34,48 \%$ concordaram. A discordância total foi de apenas 3,45\%, que significa 1 respondente.

Este resultado corrobora as construções teóricas de Francione (2013), Naconecy (2014), Regan (2006), Felipe (2007), Singer (2004), Ataíde Junior (2018), Lourenço (2016) e outros, que pleiteiam que os animais não são coisas, são seres sencientes dotados de dignidade própria, com direito moral a um rol de direitos fundamentais que lhes garantam estar a salvo de práticas cruéis e maus-tratos, sendo, consequentemente, inconstitucional submetê-los à prática de exportação por via marítima para abate no exterior, tendo vista as evidências de crueldade.

Lourenço (2016) ressalta que talvez um ponto de partida interessante seja o de reconhecer a dignidade existencial dos animais, ou, ao menos, mais especificamente, dos animais considerados sencientes. Como é consabido, a dignidade é o pano de fundo moral a partir do qual se constroem as teses concessivas de direitos fundamentais e, nesse sentido, este reconhecimento poderá propiciar um ambiente mais estável para uma futura postulação de um novo estatuto jurídico para a animalidade que seja, de fato, mais efetivo.

Igualmente Ataíde Junior (2018) entende que toda dignidade deve ser protegida por direitos fundamentais, não se podendo conceber dignidade sem um catálogo mínimo desses direitos, então a dignidade animal deve ser entendida como a base axiológica de direitos fundamentais animais, os quais constituem o objeto do Direito Animal.

Considera ainda Junior (2018) que para o Direito Animal o animal não-humano interessa como indivíduo, dotado de dignidade própria e, a partir disso, como sujeito do direito fundamental à existência digna, colocado, portanto, a salvo de práticas cruéis, tendo como marco inicial para sua autonomia científica justamente a regra da proibição da crueldade contra os animais, insculpida no inciso VII do $§ 1$ ㅇ do art. 225 da Constituição Federal. 
Portanto, é da regra constitucional da proibição da crueldade que emana o princípio da dignidade animal, garantindo seu direito fundamental à existência digna, ou seja, direito fundamental e não apenas questão de compaixão.

\subsubsection{Afirmativa 6}

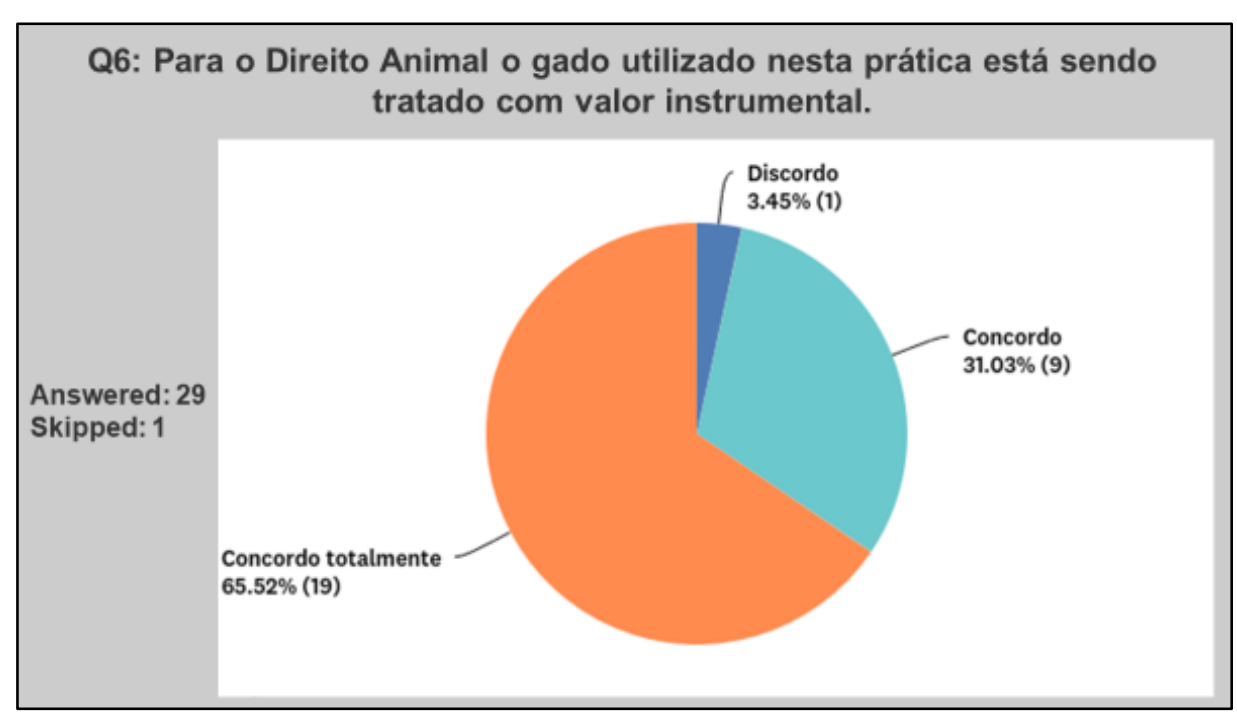

Gráfico 6 - Resultados obtidos na Afirmação 6

Fonte: Dados da pesquisa - ferramenta Survey

A afirmação 6 investiga se o animal é tratado como coisa nesta prática, com valor meramente instrumental. A maioria dos especialistas entenderam que sim, sendo $65,52 \%$ de total concordância e 31,03\% de concordância, conforme o Gráfico 6. Os respondentes que discordaram ficaram no percentual de $3,45 \%$, sendo apenas um dos respondentes.

Este resultado confirma a afirmativa 5, pois a maioria respondeu que os animais têm valor intrínseco. E corrobora a consideração de Levai (2004), quando assevera que o tratamento dado aos animais, considerando-lhes com valor meramente instrumental, é um cenário deplorável, em que o animal jamais é considerado por sua individualidade ou por sua capacidade de sofrer, mas em função daquilo que pode render.

Lourenço (2016), igualmente, afirma que a cultura prevalente sublinha a exclusividade da participação do homem na condição humana, tornando-o um sujeito (agente) moral, uma pessoa, um alguém, dotado de dignidade existencial própria, imanente, fato que the concede imediato e automático acesso aos direitos fundamentais. Por outro lado, a animalidade fica tradicionalmente conectada apenas e tão somente ao mundo instrumental. Normalmente essa posição que confere estatuto moral próprio ao homem e, paralelamente, nega esta atribuição aos animais, está conectada ao fenômeno do antropocentrismo, que significa justamente afirmar que o mundo não humano possui valor somente na medida em que atenda, direta ou indiretamente, a interesses, preferências, necessidades, utilidades ou conveniências humanas (natureza e animais possuem tão somente valor relacional; instrumental).

Portanto, se os animais não humanos são seres sencientes, significa dizer que têm dignidade própria, via de consequência, são sujeitos do direito fundamental à existência digna, devendo estar a salvo de práticas cruéis assim como o animal humano, e isto por medida de justiça e não somente de compaixão, pois por consectário lógico mereceriam um rol de direitos e consideração moral humanas, sobretudo o de não serem tratados como coisas, propriedades, instrumentos.

67 | Revista Brasileira de Direito Animal, e -issn: 2317-4552, Salvador, volume 15, n. 03, p.53 - 73, Set - Dez 2020 
Todavia, segundo Ludolf (2019) apesar dos avanços ocorridos no exterior e recentemente no Brasil, quanto a uma consideração ética e positivada inclusiva aos animais nãohumanos, a legislação que thes confere direitos e prescreve os deveres dos seres humanos para com eles ainda é afetada pela lógica antropocêntrica e especista, situando-lhes no âmbito do valor instrumental e tendo como finalidade última o benefício do ser humano. Nessa ótica o animal não é considerado como sujeito do direito ou da ética, mas objeto de direito, sem uma dignidade existencial própria que Ihe confira alguma proteção.

\subsubsection{Afirmativa 7}

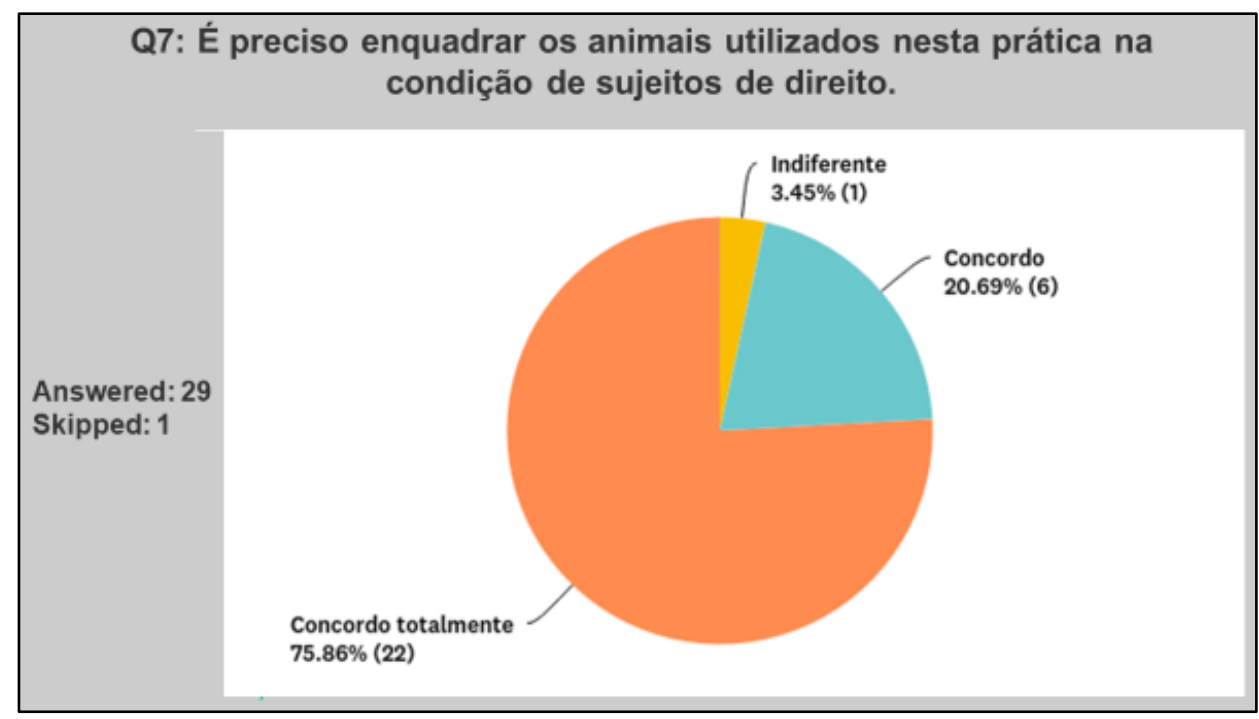

Gráfico 7 - Resultados obtidos na Afirmação 7

Fonte: Dados da pesquisa - ferramenta Survey

Para saber se os animais precisam ter sua natureza jurídica modificada, saindo da condição de objetos de direito para sujeitos de direito, ou seja, deixar a qualidade de coisa para ter sua dignidade reconhecida, elaborou-se a afirmação 7 - Gráfico 7. A maioria entendeu que sim, tendo $75,86 \%$ dos respondentes concordado totalmente com a afirmação e $20,69 \%$ concordado. Apenas um respondente foi indiferente, 3,45\%.

Autores como Santos e Medeiros (2019), Silva (2009), Ataíde Junior (2018) e Lourenço (2008) advogam que não há argumentos sólidos para que continuemos a relegar os animais à categoria meramente instrumental de coisa ou objeto. E dentre os caminhos para se alcançar esta nova condição apontam a teoria dos entes despersonalizados, que permite que se prescinda da qualificação do ente como "pessoa" para que ele venha a titularizar direitos subjetivos. A condição de sujeitos de direito é a que mais se mostra efetiva para tutelar os interesses dos animais em juízo.

Como destaca Lourenço (2008), evidentemente, consequência necessária de extensão aos animais do direito fundamental de não-sofrimento é a de torná-los "sujeitos de direito". O fato é que, se admitimos que os animais possuem um interesse qualificado e relevante no sentido do não-sofrimento, então devemos abolir, e não apenas regular, a instituição da propriedade animal. Precisamos parar de utilizar animais para finalidades nas quais não nos valeríamos de seres humanos sob as mesmas condições. 


\subsubsection{Afirmativa 8}

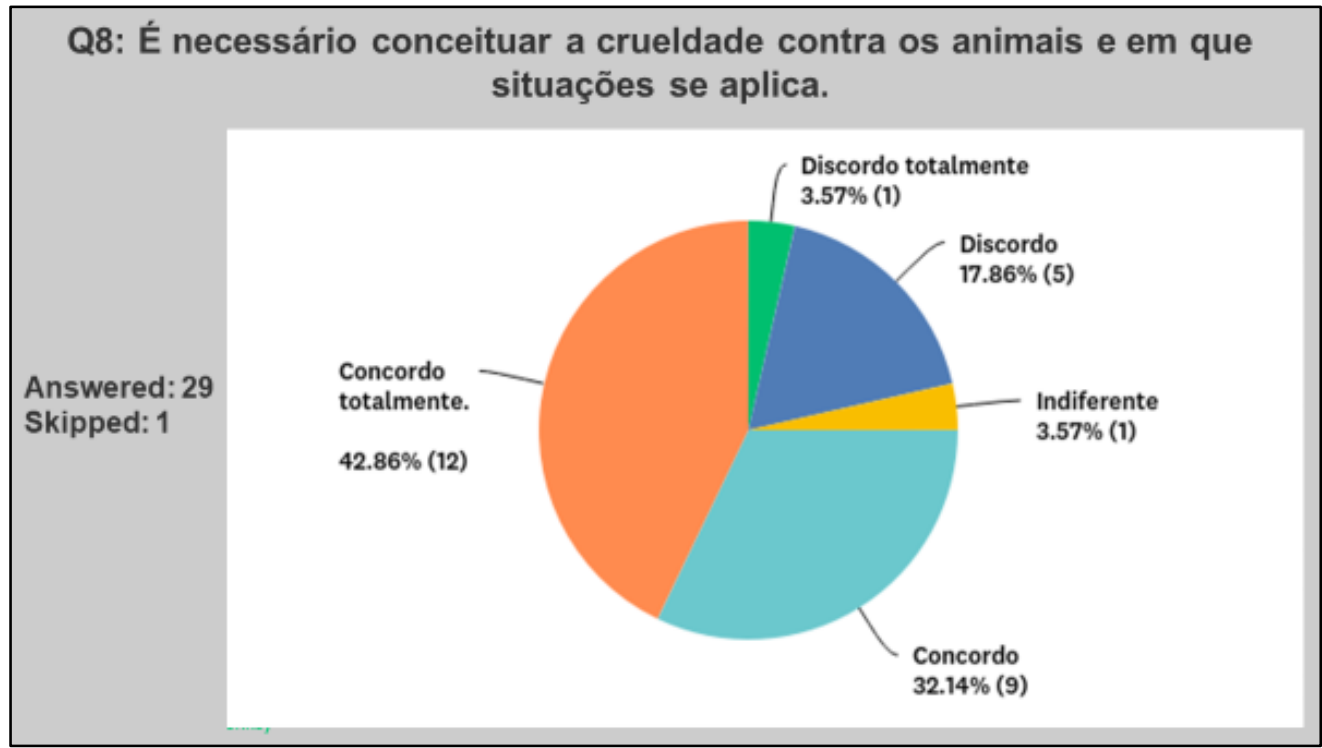

Gráfico 8 - Resultados obtidos na Afirmação 8

Fonte: Dados da pesquisa - ferramenta Survey

Por fim, a afirmação 8 do instrumento, conforme apresentado no Gráfico 8 , investigou se se faz necessário conceituar a crueldade contra os animais, delineando sua aplicabilidade, já que não há lei descrevendo o significado de crueldade. Esta foi a afirmativa com o maior número de alternativas respondidas, apesar de a maioria ter concordado com a afirmativa. $42,86 \%$ dos respondentes concordaram totalmente e $32,14 \%$ concordaram. Discordaram totalmente $3,57 \%$ e discordaram $17,86 \%$, restando 1 especialista indiferente, $3,57 \%$.

Segundo Trindade (2014), o conceito jurídico constitucional de crueldade é indeterminado. A doutrina afirma que nem toda prática cruel de fato é cruel de direito, pois existem práticas cruéis socialmente aceitas, motivo pelo qual é necessário conceituar juridicamente o termo crueldade e em que situações ela se aplica.

É cediço que a regra de vedação da crueldade se trata de norma de eficácia plena, todavia, vem sendo relativizada pelo judiciário. Por outro lado, existem normativas que podem ser utilizados para esse fim, como o decreto 24.645/34 (não revogado) e a resolução 1236/2018 do CFMV (Conselho Federal de Medicina Veterinária).

Importante que, acaso um dia se enumere o alcance da crueldade, que as hipóteses sejam exemplificativas, para que o que seja elencado como crueldade não abra margem para que o que não esteja não seja considerado cruel. Por fim, talvez o caminho mais justo e eficaz deveria ser aquele em que a crueldade, vedada constitucionalmente, fosse assumida como é, sem a relativização oriunda do modelo antropocêntrico e especista que afetou e afeta o ordenamento jurídico, limitando-a ao "sofrimento desnecessário", algo teratológico.

\section{Conclusão}

69 | Revista Brasileira de Direito Animal, e -issn: 2317-4552, Salvador, volume 15, n. 03, p.53 - 73, Set - Dez 2020 
Tais achados responderam plenamente à questão de pesquisa, evidenciando que a prática de exportação de animais vivos, com finalidade de abate, em si mesmo viola a regra constitucional de proibição de crueldade com os animais contida na parte final do inciso VII do §1으 do art. 225 da Constituição Federal, traduzindo, portanto, prática cruel e, portanto, inconstitucional.

A ação civil pública que temporariamente proibiu o navio panamenho MV NADA de seguir viagem com destino à Turquia, que impediu também a exportação de animais vivos em todo o território nacional, deflagrou um importante embate jurídico, social e legislativo, contribuindo para se investigar e concluir que esta prática viola a regra constitucional da vedação de crueldade contra os animais, regra pela qual a nova ciência jurídica do Direito Animal postula como marco inicial para sua autonomia científica, e que segue em franco desenvolvimento constitucional, legal, jurisprudencial e doutrinário no Brasil.

Diante dos dados examinados, e de acordo com os resultados do questionário aplicado, não se pode ignorar o sofrimento físico e psíquico causado aos animais submetidos a esta prática, seres dóceis e cientificamente reconhecidos como sencientes, que desde as áreas de pré-embarque, ainda na quarentena e transporte terrestre, suportam atos flagrantemente causadores de dor, aflição, humilhação, não raro lesões, doenças e mortes, sofrimentos atrozes apenas motivados pela única justificativa a favor da manutenção desta prática, o suposto benefício econômico que ela gera.

Nossa vida atribulada e cheia de preocupações faz com que automatizemos e perpetuemos determinados comportamentos de forma irrefletida. No entanto, o mundo é indivisível e os problemas ambientais e animais têm a característica da ubiquidade, afetando a tudo e a todos de forma avassaladoramente inafastável. A miopia antropocêntrica não nos permite enxergar a vida que em torno de nós palpita e nos deixa acomodados diante da triste perda proveniente do abate, da mutilação, ou da sujeição dos animais a experiências dolorosas e traumatizantes. Esse é caso do transporte de animais vivos. A mesma miopia não nos permite a sensação de empatia para com o sofrimento e a vulnerabilidade alheia.

É no estabelecimento de uma relação com o outro que se aperfeiçoa a natureza humana. Pode ser paradoxal, mas o apelo à "humanidade comum" compartilhada entre homens e não-homens pode fazer grande diferença na compreensão da necessidade de ampliação do rol dos sujeitos de direito. Se não me reconheço no outro, se não confirmo minha identidade no alter, não há sequer possibilidade de auto reconhecimento, já que a própria natureza humana não possui um sentido isolado do restante do mundo natural.

O horror específico dos navios de transporte não está no número de animais que carrega mar adentro, que de tão grande, é abstrato demais para ser concretizado por nós. 0 horror está no fato de nos recursarmos a nos colocar no lugar do outro, daqueles seres explorados, torturados e abusados, de afirmarmos que a vida importa menos para os animais que para nós. Os argumentos de ordem econômica não devem sobrepujar o reconhecimento da dignidade que cada vida animal carrega em si mesmo. Dessa forma, esta pesquisa propõe a prática de exportação de gado vivo não encontra amparo moral e jurídico e deve ser proibida em todo o território nacional.

\section{Referências}

ATAIDE JUNIOR. V. P. Introdução ao Direito Animal Brasileiro. Revista Brasileira de Direito Animal, Salvador, v. 13, n. 03, p. 48-76, set./dez. 2018. 
BRASIL. Decreto $n^{\circ} 24.645$ de 10 de julho de 1934. Estabelece medidas de proteção aos animais. Diário Oficial da União, Rio de Janeiro, RJ, 13 jul. 1948. Disponível em: http://www.planalto.gov.br/ccivil_03/decreto/1930 1949/D24645.htm. Acesso em 27 março.2019.

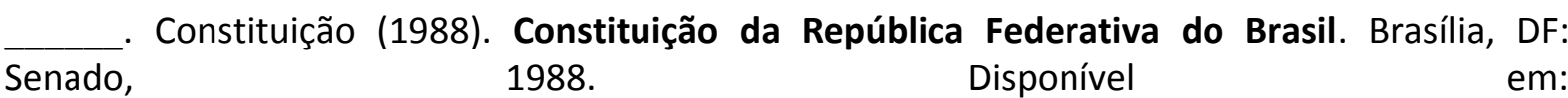
http://www.planalto.gov.br/ccivil_03/constituicao/ConstituicaoCompilado.htm. Acesso em: 25 abr. 2019.

. Ministério das Relações Exteriores. Abertura de mercado para exportações brasileiras de bovinos vivos à Malásia - nota conjunta do Ministério das Relações Exteriores e do Ministério de Agricultura, Pecuária e Abastecimento. 28 de janeiro de 2019. Disponivel em: http://www.itamaraty.gov.br/pt-BR/notas-a-imprensa/20006-nota-conjunta-do-mre-e-domapa-sobre-a-abertura-de-mercado-para-exportacoes-brasileiras-de-bovinos-vivos-para-amalasia. Acesso em: 08 fev. 2019.

BUDDLE, E. A; BRAY, H. J; ANKENY, R. A. "I Feel Sorry for Them": Australian Meat Consumers. Animals, Adelaide, Australia, v. 8, n. 10, 171, Oct. 2018.

CAULFIELD, M. P.; CAMBRIDGE, H.; FOSTER, S. F.; MCGREEVY, P. D. Heat stress: A major contributor to poor animal welfare associated with long-haul live export voyages. The Veterinary Journal, v. 199, n. 2, p. 223-228, Feb. 2014.

COLLINS, T.; HAMPTON, J.O; BARNES, A. L. A Systematic Review of Heat Load in Australian Livestock Transported by Sea. Animals, Murdoch, Australia, v. 27, n. 8, p. 164, Sep. 2018.

CONSELHO FEDERAL DE MEDICINA VETERINÁRIA. 2018. Resolução no 1236, de 26 de outubro de 2018. Disponível em: http://portal.cfmv.gov.br/lei/index/id/903

ETCO - GRUPO DE ESTUDO E PESQUISAS EM ETOLOGIA E ECOLOGIA ANIMAL. Disponível em http://www.grupoetco.org.br/arquivos br/imag index/MANIFESTO\%20BEM-

ESTAR\%20ANIMAL\%20\%20-

\%2OREFLEX\%C3\%95ES\%20SOBRE\%200S\%20ACONTECIMENTOS\%20NO\%20PORTO\%20DE\%20SA NTOS.pdf

FELIPE, S. T. Agência e Paciência Moral: Razão e Vulnerabilidade na Constituição Da Comunidade Moral. Ethic@, Florianópolis, v.6, n.4 p.69-82, ago 2007.

FRANCIONE, G. L. Introdução aos direitos animais. Campinas: Unicamp, 2013.

GONÇALVES, R. Exportação de bovino vivo: problemas, riscos e soluções. Trabalho elaborado para a Sociedade Mundial de Proteção Animal. 2008.

GORDILHO, H. J. S. Abolicionismo animal. Salvador: Evolução, 2008.

LEVAI, L. Os animais sob a visão da ética. Congresso Ambiental do Ministério Público. Campos de Jordão. $2001 . \quad$ Disponível em: 
http://www.mp.go.gov.br/portalweb/hp/9/docs/os_animais_sob_a_visao_da_etica.pdf $>$ Acesso em: 04 ago. 2016.

LIMA, Fernando Bezerra de Oliveira. Habeas Corpus para animais: Admissibilidade do HC "Suíça". Revista Brasileira de Direito Animal, Salvador, v. 3, n. 2, p. 155-192, jul./dez. 2007. Universidade Federal da Bahia. Disponível em: https://portalseer.ufba.br/index.php/RBDA/article/ view/10362. Acesso em: 7 abr. 2018. DOI: http://dx.doi.org/10.9771/rbda.v2i3.10362.

LOURENÇO, D. B. Direito dos animais: fundamentação e novas perspectivas. Porto Alegre: Sérgio Antonio Fabris Editor, 2008.

LOURENÇO, D. B. As propostas de alteração do estatuto jurídico dos animais em tramitação no Congresso Nacional brasileiro. Revista Jurídica Luso-Brasileira, ano 2, n. 1, p. 811-839, 2016.

LUDOLF, Rafael V. Exportação de Gado Vivo No Brasil: Uma Proposta Para Garantia da Regra Constitucional da Proibição da Crueldade contra os Animais sob a Ótica do Direito Animal. 2019. Dissertação. UFF. Disponível em: https://sucupira.capes.gov.br/sucupira/public/consultas/coleta/trabalhoConclusao/viewTrabalh oConclusao.xhtml?popup=true\&id trabalho $=7706470$

MEDEIROS, L. L. de. Direitos dos animais não-humanos. 2014. Disponível em: http://www.andremedeiros.com.br/files/DireitoAnimal.pdf. Acesso em: 20 abr. 2018.

MOORE, S. J.; MADIN, B.; NORMAN, G.; PERKINS, N. R.; Risk factors for mortality in cattle during live export from Australia by sea. Australian Veterinary Journal, v. 93, n. 10, Oct. 2014.

NACONECY, C. Ética e Animais. Um guia de argumentação filosófica. Porto Alegre: EDIPUCRS, 2014.

OLIVEIRA, F. C. S. de; LOURENÇO, D. B. Em prol do Direito dos Animais: inventário, titularidade e categorias. Jurispoiesis (Rio de Janeiro), v. 12, p. 113-157, 2009.

PHILLIPS, C. J. C.; PINE, M. K. Microclimatic conditions and their effects on sheep behavior during a live export shipment from Australia to the Middle East. J. Anim. Sci., v. 91, n. 9, p. 4406-4416, 2013.

PHILLIPS, C. J. C.; SANTURTUN, E. The welfare of livestock transported by ship. The Veterinary Journal, 196, p. 309-314, 2013.

REGAN, T. Jaulas vazias. Encarando o desafio dos direitos dos animais. Porto Alegre: Lugano, 2006.

SANTOS, L. M.; MEDEIROS, F. L. F. Um olhar sobre a proteção animal no direito civil sob a perspectiva comparada. RJLB, Ano 5, n. 1, p. 1283-1310, 2019.

SILVA, T. T. de A. Capacidade de ser parte dos animais não-humanos: repensando os institutos da substituição e representação processual. Revista Brasileira de Direito Animal, Salvador: Evolução, Ano 4, n. 05, p. 323-352, jan./dez. 2009. 
SINCLAIR, M.; DERKLEY, T.; FRYER, C.; PHILLIPS, C J. C. Australian Public Opinions Regarding the Live Export Trade before and after an Animal Welfare Media Exposé. Animals, Queensland, Australia, v. 8, n. 7, p. 106, Jul. 2018.

SINGER, Peter. Libertação Animal. Porto Alegre: Lugano, 2004.

SIMPSON, L. Exportação de animais vivos - DESCUMPRIMENTO DO CÓDIGO SANITÁRIO PARA ANIMAIS $\quad$ TERRESTRES $\quad-\quad$ OIE. https://docs.wixstatic.com/ugd/da8c09 9099f8f401cd49e18b4e5c8b45ff2e06.pdf

SWEENEY, D. J.; WILLIAMS, T. A.; ANDERSON, D. R. Estatística aplicada à administração e economia. São Paulo: Cengage Learnig, 2013.

TRINDADE, G. G; NUNES, L. L. Resenha: Gary L. Francione \& Robert Garner -The animal rights debate: abolition or regulation? Intuitio, Porto Alegre, v. 4, n. 2, p. 248-252, nov. 2011.

TRIBUNAL REGIONAL FEDERAL DA 3a REGIÃO. 2019. Disponível em: https://pje2g.trf3.jus.br/pje/ConsultaPublica/DetalheProcessoConsultaPublica/listView.seam?ca $=3 \mathrm{~b} 509 a f 1 d 359455 \mathrm{e} 5 \mathrm{c} 47 \mathrm{e} 89 \mathrm{a} 72 \mathrm{ca} 469139 \mathrm{~b} 484 \mathrm{~d} 172 \mathrm{~d} 84 \mathrm{~d} 8 \mathrm{e}$ 